\title{
Axenic Growth of Dictyostelium discoideum Wild-type NC-4 Cells and its Relation to Endocytotic Ability
}

\author{
By YASUO MAEDA $\dagger$ \\ Department of Botany, Faculty of Science, Kyoto University, Kyoto 606, Japan
}

(Received 8 December 1982; revised 8 March 1983)

\begin{abstract}
A method for the axenic growth of Dictyostelium discoideum wild-type strain NC-4 is described. There were some differences between the nutritional requirements of strain NC-4 and an axenic strain Ax-2 derived from NC-4. Of the numerous components in growth media, the nature and concentration of the peptone was especially critical for axenic growth of NC-4 cells; $3 \%$ Bacteriological-peptone (Oxoid) giving the best growth rate and yield. NC-4 cells seemed to require more vitamin $B_{12}$ than $A x-2$ cells. Other vitamins like folic acid, biotin, and riboflavin also stimulated axenic growth of NC-4 cells. Pinocytosis was examined by the use of FITC-dextran and the results showed that the above peptone considerably enhanced the pinocytotic activity of both NC-4 and Ax-2 cells. Bacto-peptone (Difco) also enhanced pinocytosis to a similar extent, though it never supported axenic growth of NC-4 cells. Therefore, stimulation of pinocytosis may be necessary for nutrient uptake, but is not sufficient for axenic growth. The pinocytotic ability of cells decreased conspicuously during the course of development, particularly just before aggregation. The biological significance of this is discussed in relation to cell differentiation.
\end{abstract}

\section{INTRODUCTION}

Vegetative cells of the cellular slime mould Dictyostelium discoideum grow and divide as solitary amoebae, feeding on bacteria by phagocytosis. In the differentiation phase, the amoebae associate together to form aggregates that, in a period of organized movement, form fruiting bodies consisting of a mass of spores (sorus) and a supporting cellular stalk.

Up to now, it has been extremely difficult to grow wild-type cells of $D$. discoideum axenically. Sussman \& Sussman (1967) reported the isolation of axenically grown cells from $D$. discoideum wild-type strain NC-4 by the serial passage of this species in a relatively simple medium. Although Yamada et al. (1974) reported that dialysable substances prepared from Aerobacter aerogenes cultures support axenic growth of NC-4 cells, this was non-repeatable (personal communication). Two mutant strains, Ax-2 (Watts \& Ashworth, 1970) and Ax-3 (Loomis, 1971), both derived from NC-4, can grow axenically in a medium containing Bacteriological-peptone, yeast extract, and inorganic salts. Watts \& Guest (1975) and Watts (1977) revealed vitamin requirements for the growth of Ax-2. Furthermore, Franke \& Kessin (1977) developed a defined minimal medium for $\mathrm{Ax}-3$, in which peptone and yeast extract were replaced by amino acids and vitamins, respectively.

During the feeding phase, cells must incorporate nutrients, particularly those of high molecular weights, by endocytosis into the cytoplasm via vesicles derived from the plasma membrane. The endocytosis is divided into two types: the uptake of fluid (pinocytosis) and that of particles (phagocytosis). Wild-type (NC-4) cells actively engulf bacteria like Escherichia coli by phagocytosis during vegetative growth, while $\mathrm{Ax}-3$ cells exhibit active pinocytosis in addition to phagocytosis (Vogel et al., 1980). The failure of NC-4 cells to grow axenically could be due to a

$\dagger$ Present address: Biological Institute, Faculty of Science, Tohoku University, Aoba-Yama, Sendai 980, Japan. 
deficiency of their pinocytotic activity. Alternatively, there may be marked differences in nutritional requirements between $\mathrm{NC}-4$ and $\mathrm{Ax}-3$ cells.

This paper describes an axenic growth medium for NC-4 cells and relates growth to pinocytotic ability. A developmental change of pinocytotic activity is also described, and its biological significance discussed in relation to cell growth and differentiation.

\section{METHODS}

Chemicals. Commercially available chemicals were used: Bacteriological-peptone (Oxoid), Bacto-peptone (Difco), Poly-peptone (Daigo Nutritional Chemical Co. Ltd, Osaka, Japan), Proteose-peptone (Daigo), Bactotryptone (Difco), yeast extract (Oxoid), Bacto-agar (Difco), FITC-dextran 70S (fluorescein isothiocyanate dextran, Sigma). All other chemicals were reagent grade and supplied by Nakarai Chemical Co. Ltd, Kyoto, Japan.

Organisms. A wild-type strain (NC-4) and its mutant (Ax-2) of Dictyostelium discoideum were mainly used in this study. Dictyostelium mucoroides no. 11 and Polysphondylium violaceum P6 were used for comparison.

Culture conditions. Amoebae of $D$. discoideum NC-4, D. mucoroides, and $P$. violaceum were separately grown with Escherichia coli $\mathrm{B} / \mathrm{r}$ on standard nutrient agar (Bonner, 1947). Mature fruiting bodies were formed on the agar plate after $6 \mathrm{~d}$ incubation at $21-22^{\circ} \mathrm{C}$, and their sori were taken up carefully, to prevent bacterial contamination, using a sterilized needle. Spores thus obtained were inoculated into various nutrient media $(20 \mathrm{ml})$ in $125 \mathrm{ml}$ flasks. Cultures (about $2 \times 10^{4}$ spores $\mathrm{ml}^{-1}$ ) were incubated on a gyratory shaker at 180 r.p.m. at $21-22^{\circ} \mathrm{C}$. The absence of bacterial contamination was established by microscopic inspection at various periods of incubation. Dictyostelium discoideum Ax-2 cells were grown with shaking in HL-5 medium (Bacteriological-peptone, $1.5 \%$ (w/v); yeast extract, $\left.0.7 \% ; \mathrm{Na}_{2} \mathrm{HPO}_{4} .12 \mathrm{H}_{2} \mathrm{O}, 1.28 \mathrm{~g} \mathrm{l}^{-1} ; \mathrm{KH}_{2} \mathrm{PO}_{4}, 0.486 \mathrm{~g} \mathrm{l}^{-1}\right)$ containing $1.5 \%(\mathrm{w} / \mathrm{v})$ glucose. To allow the cells to develop, cells were harvested at the late-exponential growth phase and incubated on $2 \%$ nonnutrient agar at $21-22^{\circ} \mathrm{C}$. Aggregation-competent cells were obtained after about $6 \mathrm{~h}$ incubation under this condition.

Assay for pinocytosis. FITC-dextran 70S (Sigma) was used as a fluid phase marker, as described by Vogel et al. (1980). Washed amoebae were suspended at a density of $4-5 \times 10^{6}$ cells ml $^{-1}$ in $10 \mathrm{~mm}$-phosphate buffer $(\mathrm{pH} 6 \cdot 2)$ containing various nutrients, and FITC-dextran was added to a final concentration of $3 \mathrm{mg} \mathrm{ml}^{-1}$. This was followed by incubation on a reciprocal shaker at 150 r.p.m. at $22^{\circ} \mathrm{C}$. Pinocytosis was stopped by diluting $2 \mathrm{ml}$ samples at various times into $8 \mathrm{ml}$ ice-cold $10 \mathrm{mM}$-phosphate buffer, $\mathrm{pH} 6 \cdot 2$. Cells were collected by centrifugation for $2 \mathrm{~min}$ at 1500 r.p.m. and resuspended in phosphate buffer. After washing once, the cells were suspended in $2 \mathrm{ml}$ phosphate buffer, and centrifuged through $10 \%(\mathrm{w} / \mathrm{w})$ sucrose for $3 \mathrm{~min}$ at 2500 r.p.m. Cells were resuspended in $3 \mathrm{ml} 50 \mathrm{~mm}-\mathrm{Na}_{2} \mathrm{HPO}_{4}$ after washing once in phosphate buffer, and the cell number was counted using a haematocytometer. Subsequently, cells were lysed by addition of Triton X-100 $(0 \cdot 2 \%$ final concentration). The fluorescence intensity of the solution was measured by a fluorometer (excitation wavelength, $470 \mathrm{~nm}$; emission wavelength, $520 \mathrm{~nm}$ ), and the amount pinocytosed determined by comparison with a standard curve.

\section{RESULTS}

\section{Conditions for axenic growth of $D$. discoideum $N C-4$}

In an attempt to find an axenic growth medium for $D$. discoideum $\mathrm{NC}-4$, its spores were inoculated into various media listed in Table 1 , and their growth monitored after shaking at $21-$ $22{ }^{\circ} \mathrm{C}$. The best medium was composed of: $3 \%$ Bacteriological-peptone (Oxoid), $0.4 \%$ yeast extract, $1 \%$ glucose, $\mathrm{Na}_{2} \mathrm{HPO}_{4} .12 \mathrm{H}_{2} \mathrm{O}\left(1.28 \mathrm{~g} \mathrm{l}^{-1}\right), \mathrm{KH}_{2} \mathrm{PO}_{4}\left(0.486 \mathrm{~g} \mathrm{l}^{-1}\right)$, vitamin $\mathrm{B}_{12}$ $\left(5 \mu \mathrm{g} \mathrm{ml}^{-1}\right)$, folic acid $\left(4 \mu \mathrm{g} \mathrm{ml}^{-1}\right)$, D-biotin $\left(1 \mu \mathrm{g} \mathrm{ml}^{-1}\right)$, riboflavin $\left(1 \mu \mathrm{g} \mathrm{ml}^{-1}\right)$, thiamin. $\mathrm{HCl}$ $\left(1 \mu \mathrm{g} \mathrm{ml}^{-1}\right), 25 \mu \mathrm{M}-\mathrm{FeCl}_{3}, 25 \mu \mathrm{M}-\mathrm{ZnCl}_{2}, 4.5 \mathrm{mM}-\mathrm{CaCl}_{2}$, and $0.5 \mathrm{mM}-\mathrm{MgCl}_{2}$ (the first column of Table 1). This medium is referred to as MA-medium. NC-4 cells grew exponentially in this medium, after a lag of about $8 \mathrm{~h}$, with a doubling time of about $11 \mathrm{~h}$ and a stationary phase yield of $4 \times 10^{6}$ cells ml-1. The same result was obtained with $\mathrm{NC}-4$ spores incubated in MA-medium containing an antibiotic $\left(250 \mu \mathrm{g}\right.$ streptomycin $\left.\mathrm{ml}^{-1}\right)$. Furthemore, no bacterial growth was detected when NC-4 cells taken late in growth of the culture were incubated on Bonner's nutrient agar at a temperature $\left(36-37^{\circ} \mathrm{C}\right)$ that would have killed slime mould amoebae but encouraged growth of any contaminants. This indicates the absence of bacterial contamination during incubation of NC-4 cells. A major part of the lag before growth might be the period required for spore germination. As shown in Table 1, medium lacking Bacteriological-peptone never supported growth, though spore germination was normal. When the concentration of the 
Table 1. Axenic growth conditions for D. discoideum NC-4 cells

Cultures were shaken in a gyratory shaker at 180 r.p.m. at $21-22{ }^{\circ} \mathrm{C}$. A standard (MA) medium was composed of : $3 \%$ Bacteriological-peptone (Oxoid), $1 \%$ glucose, $0 \cdot 4 \%$ yeast extract, $\mathrm{Na}_{2} \mathrm{HPO}_{4} \cdot 12 \mathrm{H}_{2} \mathrm{O}$ $\left(1 \cdot 28 \mathrm{~g} \mathrm{l}^{-1}\right), \mathrm{KH}_{2} \mathrm{PO}_{4}\left(0.486 \mathrm{~g} \mathrm{ml}^{-1}\right)$, vitamin $\mathrm{B}_{12}\left(5 \mu \mathrm{g} \mathrm{ml}^{-1}\right)$, folic acid $\left(4 \mu \mathrm{g} \mathrm{ml}^{-1}\right)$, D-biotin $\left(1 \mu \mathrm{g} \mathrm{ml}^{-1}\right)$, riboflavin $\left(1 \mu \mathrm{g} \mathrm{ml}^{-1}\right)$, thiamin. $\mathrm{HCl}\left(1 \mu \mathrm{g} \mathrm{ml}^{-1}\right), 4.5 \mathrm{~mm}-\mathrm{CaCl}_{2}, 0.5 \mathrm{~mm}-\mathrm{MgCl}_{2}, 25 \mu \mathrm{M}-$ $\mathrm{FeCl}_{3}$, and $25 \mu \mathrm{M}-\mathrm{ZnCl}_{2}$. The $\mathrm{MA}$-medium was modified by omission or addition of substances indicated below.

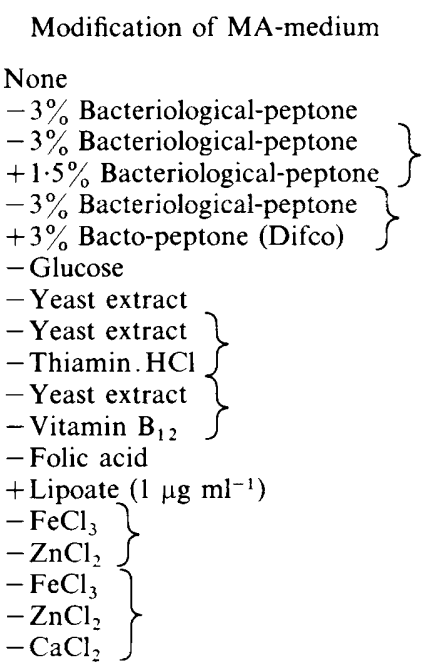

$$
\begin{gathered}
\begin{array}{c}
\text { Final cell yield } \\
\left(\text { cells } \mathrm{ml}^{-1}\right)
\end{array} \\
4 \times 10^{6} \\
\text { No growth } \\
2 \times 10^{6} \\
\text { No growth } \\
2 \cdot 4 \times 10^{6} \\
3 \cdot 2 \times 10^{6} \\
\text { No growth } \\
4 \times 10^{5} \\
2 \cdot 8 \times 10^{6} \\
\text { No growth } \\
2 \times 10^{6} \\
8 \times 10^{5}
\end{gathered}
$$

peptone was reduced to $1.5 \%$, both growth rate and yield were halved, indicating the importance of the peptone for axenic growth. A higher concentration $(5 \%)$ of peptone, showed no further stimulation of growth, and rather had a slight inhibitory effect. If Bacteriologicalpeptone was replaced by Bacto-peptone (Difco), no growth was detected though the spores germinated normally. Substitution of Bacto-tryptone (Difco) or Poly-peptone (Daigo) for Bacteriological-peptone caused a considerable decrease in both growth rate and yield, the final yield being $8 \times 10^{5}$ cells $\mathrm{ml}^{-1}$ and $4 \times 10^{5}$ cells $\mathrm{ml}^{-1}$, respectively. Proteose-peptone (Daigo) supported growth to a certain extent, but the final yield was $2 \times 10^{6}$ cells $\mathrm{ml}^{-1}$. Thus, the kind and concentration of peptone used are of particular importance for axenic growth. In addition, both growth rate and yield were found to vary depending on the batch of Bacteriologicalpeptone used.

The maximum growth rate and yield were not affected by doubling the concentration of yeast extract in MA-medium. Indeed omission of yeast extract had no great effect on growth, suggesting that five vitamins included in MA-medium could substitute for yeast extract almost completely. However, no growth occurred in MA-medium lacking both yeast extract and thiamin. $\mathrm{HCl}$. Eliminating yeast extract and vitamin $\mathbf{B}_{12}$ (cyanocobalamin) caused a conspicuous decrease in both growth rate and yield $\left(4 \times 10^{5}\right.$ cells $\left.\mathrm{ml}^{-1}\right)$. Since the final yield was reduced to $2.8 \times 10^{6}$ cells $\mathrm{ml}^{-1}$ when folic acid, D-biotin, or riboflavin was omitted from MAmedium, relatively high concentrations of these vitamins seem to be required for axenic growth of NC-4 cells. On the other hand, the addition of lipoate $(1 \mu \mathrm{g} \mathrm{ml})$ to MA-medium inhibited growth completely.

The best concentration of glucose for growth was close to $1 \%(w / v)$. Without glucose, the final density did not exceed $2.4 \times 10^{6}$ cells $\mathrm{ml}^{-1}$. D-Maltose could substitute for glucose at a concentration of $1 \%$.

Since tryptophan and tyrosine are known to be present at higher concentrations in Bacteriological-peptone compared to Bacto-peptone, we tested whether these amino acids could stimulate growth. However, the addition of tryptophan and/or tyrosine to MA-medium at 
concentrations of $20-100 \mu \mathrm{g} \mathrm{ml}^{-1}$ did not improve growth rate or yield. Furthermore, addition of methionine, histidine, glycine, or phenylalanine to MA-medium at concentrations of 20 $100 \mu \mathrm{g} \mathrm{ml}^{-1}$ also had no significant effect on growth.

In all the situations examined, the doubling time of the cells was found to be inversely proportional to the final cell yield.

When a small number of vegetative NC-4 cells grown axenically were transferred into fresh MA-medium, they grew exponentially up to $4 \times 10^{6}$ cells $\mathrm{ml}^{-1}$ without a lag and with a generation time of about $11 \mathrm{~h}$. Following growth in MA-medium, the NC-4 cells could not continue growth when they were transferred into fresh HL-5 glucose medium in which Ax- 2 cells were able to grow. This suggests that the wild-type strain NC-4 used does not carry axenic mutations. In addition, when Ax-2 cells were incubated in the supernatant of MA-medium in which NC-4 cells had ceased to grow, they could continue to grow up to a density of about $1.2 \times 10^{7}$ cells $\mathrm{ml}^{-1}$.

Axenically grown NC-4 cells were slightly smaller in size than those grown on living bacteria, and in addition a fair number of small cell clumps formed when the cells reached stationary phase. When these cells were harvested and plated on non-nutrient $2 \%$ agar, they developed normally to form fruiting bodies. Axenically grown NC-4 cells were found to be mononucleate when examined with a phase-contrast microscope, this is in contrast to Ax-2 cells in axenic culture which tend to be multinucleate and larger than the mononucleate amoebae grown with bacterial substrates.

Dictyostelium mucoroides and $P$. violaceum never grew in MA-medium, while $D$. discoideum Ax-2 cells grew well with generation time of about $8 \mathrm{~h}$, up to a density of $1.6 \times 10^{7}$ cells ml $^{-1}$. However, growth of $\mathrm{Ax}-2$ cells was very poor when Bacto-peptone was used instead of Bacteriological-peptone, as was the case for NC-4 cells.

\section{Pinocytotic activities of $A x-2$ and NC-4 cells}

Pinocytosis by axenically-grown cells was measured using FITC-dextran as a fluid marker. Uptake of FITC-dextran by Ax-2 cells proceeded linearly with time for at least $90 \mathrm{~min}$. As shown in Table 2, the uptake of FITC-dextran was considerably lower in $1.5 \%$ glucose or $0.7 \%$ yeast extract compared with that in $1.5 \%$ Bacteriological-peptone. In a medium containing $1.5 \%$ Bacteriological-peptone, $1.5 \%$ glucose, and $0.7 \%$ yeast extract, the uptake of FITCdextran was the same as that in $1.5 \%$ Bacteriological-peptone alone. Bacto-peptone also gave nearly the maximum uptake and similar results were obtained with NC-4 cells grown axenically, though the absolute amounts FITC-dextran taken up were markedly lower than with Ax-2 cells. Possibly, such a difference in uptake is partly due to the larger size of Ax-2 cells compared with NC- 4 cells. In fact, NC-4 cells as well as Ax- 2 cells were seen under the fluorescence microscope to contain numerous pinosomes with FITC-dextran after 90 min incubation in $1.5 \%$ Bacteriological-peptone. The pinocytotic ability of Ax-2 cells, however, seems to be substantially greater than that of NC-4 cells, due to a genetic difference between the two. These results clearly indicate that peptone considerably enhances the pinocytotic activities of both Ax-2 and NC-4 cells.

We also examined the pinocytosis of washed NC-4 cells that had been grown on $E$. coli. When these cells were shaken in $1.5 \%$ Bacteriological-peptone, they began to incorporate FITCdextran after a lag of about $3 \mathrm{~h}$ (Fig. 1). Although the reason for the lag is not known, it is possible that cells require a certain period to switch from phagocytotic to pinocytotic activity. Alternatively, a difference in preculture conditions before the start of the shake culture (shaking or stationary) might be responsible.

When examined under the fluorescence microscope, vegetative cells of $D$. mucoroides and $P$. violaceum had no pinosomes with FITC-dextran even after $6 \mathrm{~h}$ of shake culture in $1.5 \%$ Bacteriological-peptone, indicating a lack of pinocytotic ability. This could explain the failure of these cells to grow axenically. 
Table 2. FITC-dextran incorporation under various conditions

Dictyostelium discoideum Ax-2 or NC-4 cells at the vegetative phase were shaken for 90 min at $22^{\circ} \mathrm{C}$.

\begin{tabular}{|c|c|c|}
\hline \multirow[b]{2}{*}{ Medium* } & \multicolumn{2}{|c|}{$\begin{array}{c}\text { FITC-dextran incorporated in } 90 \mathrm{n} \\
\left(\mu \mathrm{g} \text { per } 10^{7} \text { cells }\right)\end{array}$} \\
\hline & Ax -2 cells & NC-4 cells \\
\hline $1.5 \%$ Glucose & $6 \cdot 8$ & 0.43 \\
\hline $0.7 \%$ Yeast extract (Oxoid) & $8 \cdot 4$ & $0 \cdot 65$ \\
\hline $1.5 \%$ Bacteriological-peptone (Oxoid) & 13.6 & $1 \cdot 15$ \\
\hline $1.5 \%$ Bacto-peptone (Difco) & $12 \cdot 8$ & $1 \cdot 10$ \\
\hline $1.5 \%$ Glucose & & \\
\hline $\begin{array}{l}0.7 \% \text { Yeast extract (Oxoid) } \\
1.5 \% \text { Bacteriological-peptone (Oxoid) }\end{array}$ & $13 \cdot 6$ & $1 \cdot 12$ \\
\hline
\end{tabular}

* All media contained $3 \mathrm{mg}$ FITC-dextran $\mathrm{ml}^{-1}$ in $10 \mathrm{~mm}$-sodium/potassium phosphate buffer, pH 6.2.

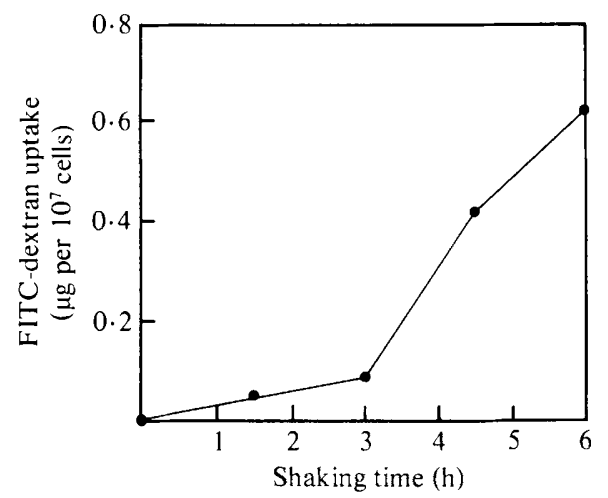

Fig. 1. Uptake of FITC-dextran by $D$. discoideum NC-4 cells that had been grown with $E$. coli and harvested. Cells were shaken in $1.5 \%$ Bacteriological-peptone containing FITC-dextran $\left(3 \mathrm{mg} \mathrm{ml}^{-1}\right)$ at $22{ }^{\circ} \mathrm{C}$ and at various times the dextran incorporated was determined.

Table 3. A change in the ability of Ax-2 cells to incorporate FITC-dextran during development

Dictyostelium discoideum Ax-2 cells were shaken for $90 \mathrm{~min}$ at $22^{\circ} \mathrm{C}$ in $10 \mathrm{~mm}$-sodium/potassium phosphate buffer, pH 6.2, containing 1.5\% Bacteriological-peptone (Oxoid) and $3 \mathrm{mg}$ FITC-dextran $\mathrm{ml}^{-1}$.

Developmental stage of cells

Vegetative $\left(t_{0}\right)$
Interphase $\left(t_{3}\right)$
Aggregation-competent $\left(t_{6}\right)$
FITC-dextran incorporated in $90 \mathrm{~min}$ ( $\mu \mathrm{g}$ per $10^{7}$ cells)

$$
\begin{array}{r}
13.6 \\
9.0 \\
1.7
\end{array}
$$

Developmental changes in the pinocytotic activity of $A x-2$ cells

Changes in the rate of FITC-dextran uptake were examined by shaking Ax-2 cells, taken at various developmental stages, for $90 \mathrm{~min}$ in the presence of $1.5 \%$ Bacteriological-peptone (Table 3 ). Vegetative $\left(t_{0}\right)$ cells showed active pinocytosis, as described in the preceding section, while the rate of FITC-dextran uptake by aggregation-competent $\left(\mathrm{t}_{6}\right)$ cells was much lower. Interphase $\left(t_{3}\right)$ cells gave an intermediate value. These results indicate that the pinocytotic ability was greatly reduced during development, particularly immediately before the aggregation stage. 


\section{Preservation of the growth medium}

During the course of these experiments, it was found that the media for axenic culture were highly sensitive to light. For instance, HL-5 medium containing $1.5 \%$ glucose which had been exposed to a fluorescent light $(15 \mathrm{~W})$ for $5 \mathrm{~d}$ never supported axenic growth of Ax-2 cells. When exposed for $3 \mathrm{~d}$, a considerable decrease in growth rate and yield was observed. In this case, the addition of $2 \mathrm{~mm}$-tryptophan restored the effectiveness of the medium almost completely. However, tryptophan was no longer completely effective in restoring media exposed for longer periods. The medium exposed for a long time was in fact inhibitory to cell growth when mixed with freshly prepared HL-5 medium. Medium was stable in the dark for at least 3 weeks and supported the growth of Ax-2 cells as well as did a freshly prepared medium. This was also true for NC-4 cells.

Pinocytosis by Ax-2 cells was not significantly different in fresh medium or medium exposed to light for $5 \mathrm{~d}$. This indicates the presence in the medium of some substances which when irradiated become strongly inhibitory to cell growth. In any case, care must be taken not to expose the medium to light before use.

\section{DISCUSSION}

The major achievement of the present work was the development of a medium for the axenic growth of $D$. discoideum wild-type NC-4. This was done both by the selection of a suitable peptone and by the addition of vitamins, such as $B_{12}$, to the media. Even so the growth rate and final yield of cells were lower compared with the axenic strain Ax-2 derived from NC-4. The kind of peptone used was of particular importance, because Bacteriological-peptone (Oxoid) but not Bacto-peptone (Difco) supported axenic growth of NC-4 cells. Considering the fact that Bacto-peptone as well as Bacteriological-peptone considerably enhanced pinocytosis in both NC-4 and Ax-2 cells, it is likely that nutrient uptake by pinocytosis is necessary for axenic growth, but not sufficient. Although the growth stimulating factors contained in Bacteriologicalpeptone are presently unknown, our preliminary experiments indicate that they have relatively high molecular weights (5000-10000). To improve the growth rate and yield, identification of the growth factors will be necessary.

The vitamin requirements for axenic growth of NC-4 cells were essentially similar to those of Ax-2 (Watts, 1977) and Ax-3 (Franke \& Kessin, 1977). Franke \& Kessin (1977) examined two strains of $A x-3$ and showed that only one of them required vitamin $B_{12}$, though the requirement did not appear until the cells had grown for about 10 generations in a medium lacking vitamin $\mathbf{B}_{12}$. Vitamin $\mathbf{B}_{12}$ is usually needed only in low concentrations and perhaps there was sufficient contamination of the defined culture media with this vitamin to allow growth of the Ax-2 and $A x-3$ strains which appeared not to need vitamin $B_{12}$. However, the present work showed that relatively high concentrations of vitamin $B_{12}$ are required for enhancement of axenic growth of $\mathrm{NC}-4$ cells. It has been reported that lipoate is not necessary for the growth of Ax-3 (Franke \& Kessin, 1977) and Ax-2 (Watts, 1977), but the final density without lipoate did not exceed about $10^{6}$ cells $\mathrm{ml}^{-1}$. However, the addition of lipoate to MA-medium had a rather inhibitory effect on the growth of NC-4 cells. Although the lipoate content of MA-medium is unknown, there might be sufficient for cell growth, and more than this becomes inhibitory. This also raised the possibility that lipoate is one of factors limiting growth of NC-4 cells in MA-medium. The requirements of metals like $\mathrm{Fe}^{3+}, \mathrm{Zn}^{2+}$ and $\mathrm{Mg}^{2+}$ for growth of $\mathrm{NC}-4$ cells are in agreement with those for Ax-3 cells (Franke \& Kessin, 1977). However the addition of $\mathrm{Ca}^{2+}$ had a positive effect on NC-4 growth, particularly in the medium containing low levels of the above metal ions. There are clearly some differences in nutritional requirements between NC-4 and Ax-2 (or Ax-3) cells.

Slime mould amoebae usually grow by degrading bacteria ingested by phagocytosis. When vegetative cells of $D$. discoideum NC-4 were incubated with particles like $E$. coli or polystyrene latex beads in the presence of FITC-dextran, they engulfed a fair number of the particles in a short period, without incorporating much FITC-dextran into the phagosomes (data not shown). Therefore, these particles may adhere tightly to a limited portion of cell surface, which then expands to envelop the whole particle without leaving any large spaces. This is followed by 
complete internalization of the particle through membrane fusion. Vogel et al. (1980) reported that phagocytosis is mediated by certain recognition sites on the cell surface. In general, pinocytosis is considered to be a constitutive property of many cells as the mechanism of nutrient uptake, and seems to proceed with a basal rate characteristic for each cell type, sometimes being induced by relatively specific substances. However, $D$. mucoroides and $P$. violaceum cells showed no detectable pinocytosis. In these species, phagocytosis may be the sole means of nutrient uptake.

The phagocytotic activity of $D$. discoideum cells is known to decrease markedly during cell differentiation, aggregation-competent cells being almost devoid of the ability. Such a decrease was also found in pinocytotic activity, as presented here. Thus, D. discoideum cells gradually become more of a closed society during the course of development, since uptake of external materials by cells is greatly restricted after the growth phase. The endocytotic activity is another marker which distinguishes the vegetative and differentiated cells. Little is known about the cellular mechanism which controls the pinocytotic activity. Comparison of cells with and without the pinocytotic activity will help in the clarification of this mechanism.

I wish to thank Professor I. Takeuchi of Kyoto University for reading and criticizing the manuscript.

\section{REFERENCES}

BONNER, J. T. (1947). Evidence for the formation of cell aggregates by chemotaxis in the development of the slime mold Dictyostelium discoideum. Journal of Experimental Zoology 106, 1-26.

Franke, J. \& Kessin, R. (1977). A defined medium for axenic strains of Dictyostelium discoideum. Proceedings of the National Academy of Sciences of the United States of America 74, 2157-2161.

LoOMIs, W. F. (1971). Sensitivity of Dictyostelium discoideum to nucleic acid analogues. Experimental Cell Research 64, 484-486.

Sussman, R. \& Sussman, M. (1967). Cultivation of Dictyostelium discoideum in axenic medium. Biochemical and Biophysical Research Communications 29, 53-55.

Vogel, G., Thilo, L., Schwarz, H. \& Steinhart, R. (1980). Mechanism of phagocytosis in Dictyostelium discoideum: phagocytosis is mediated by different recognition sites as disclosed by mutants with altered phagocytotic properties. Journal of Cell Biology 86, 456-465.

WATTS, D. J. (1977). Vitamin requirements for growth of myxamoebae of Dictyostelium discoideum in a defined medium. Journal of General Microbiology 98, 355-361.

WatTS, D. J. \& Ashworth, J. M. (1970). Growth of myxamoebae of the cellular slime mould Dictyostelium discoideum in axenic culture. Biochemical Journal 119, 171-174.

WATTS, D. J. \& GUEST, J. R. (1975). Studies on vitamin nutrition of the cellular slime mould Dictyostelium discoideum. Journal of General Microbiology 86, 333 342.

Yamada, H., Yodomae, T. \& Miyazaki, T. (1974). Polysaccharides of the cellular slime mold. I. Extracellular polysaccharides in growth phase of Dictyostelium discoideum. Biochimica et biophysica acta 343, 371-381. 